\title{
PENGARUH KOMITMEN ORGANISASI, PENGENDALIAN INTERN AKUNTANSI, PERAN INTERNAL AUDIT, PENDIDIKAN, DAN KUALITAS PELATIHAN TERHADAP KETERANDALAN LAPORAN KEUANGAN PADA SKPD PEMERINTAH KABUPATEN HALMAHERA UTARA
}

\author{
YOKI DODOPO ${ }^{1)}$ JULLIE J SONDAKH ${ }^{2)}$ JANTJE J TINANGON ${ }^{3)}$
}

\author{
Program Studi Akuntansi Fakultas Ekonomi dan Bisnis Universitas Sam Ratulangi \\ E-mail : yokidodopo@yahoo.co.id
}

\begin{abstract}
This research aims to test the influence of such independent variables as the organizational commitment, Accounting Internal Control, The Role Of Internal Audit, Education, and the quality of training to such dependent variables as the reliability of the financial report of local government. This research uses a quantitative approach, using primary data through questionnaires. The respondents in this study were the employees who processes the financial administration and those who make financial report at the Local Working Unit (SKPD) in North Halmahera Regency Government. The population used for this research is a group of financial staff which is about 298 people in each of the SKPD, and the samples taken are 75 respondents. The data were analyzed using multiple linear regression analysis and the data were tested by using SPSS program version 22. The results of a multiple linear regression analysis shows that partially, the organizational commitment, accounting internal control, the role of internal audit, education, and the quality of training give positive impacts and significant effects to the reliability of the financial report of local government. The result of the test also shows that simultaneously, the good organizational commitment, accounting internal control, the role of internal audit, education, and quality of training give positive impacts and significant effects to the reliability of financial report of local government. The value of the coefficient of determination indicates that the organizational commitment, accounting internal control, the role of internal audit, education, and quality of training is $49.70 \%$, and the remaining $50.30 \%$ is affected by other factors which are not included in this model of research.
\end{abstract}

Keywords : Organizational Commitment, Internal Control Of Accounting, The Role Of Internal Audit, Education, Quality Of Training, The Reliability Of Financial Report.

Abstrak. Penelitian ini bertujuan untuk menguji pengaruh variabel independen yaitu Komitmen Organisasi, Pengendalian Intern Akuntansi, Peran Internal Audit, Pendidikan, dan Kualitas Pelatihan terhadap variabel dependen yaitu Keterandalan Laporan Keuangan Daerah. Penelitian ini menggunakan pendekatan kuantitatif, dengan menggunakan data primer melalui kuesioner. Responden dalam penelitian ini adalah pegawai pada bagian proses penatausahaan keuangan dan pegawai yang membuat laporan keuangan pada Satuan Kerja Perangkat Daerah (SKPD) di Pemerintah Kabupaten Halmahera Utara. Populasi yang digunakan adalah pengelola keuangan sebanyak 298 pegawai di masing-masing SKPD, sampel yang digunakan sebanyak 75 responden. Data dianalisis menggunakan analisis regresi linier berganda (Multiple linear regression) dan pengujian data dilakukan dengan dibantu oleh program SPSS versi 22. Berdasarkan hasil analisis regresi linier berganda menunjukkan bahwa secara parsial komitmen organisasi, pengendalian intern akuntansi, peran internal audit, pendidikan, dan kualitas pelatihan berpengaruh positif dan signifikan terhadap keterandalan laporan keuangan pemerintah daerah. Hasil pengujian secara simultan baik komitmen organisasi, pengendalian intern akuntansi, peran internal audit, pendidikan, dan kualitas pelatihan berpengaruh positif dan signifikan terhadap keterandalan laporan keuangan pemerintah daerah. Nilai dari koefisien determinasi menunjukkan bahwa komitmen organisasi, pengendalian intern akuntansi, peran internal audit, pendidikan, dan kualitas pelatihan yaitu sebesar $49,70 \%$, sedangkan sisanya $50,30 \%$ dipengaruhi oleh faktor lain di luar model penelitian ini.

Kata kunci : Komitmen Organisasi, Pengendalian Intern Akuntansi, Peran Internal Audit, Pendidikan, Kualitas Pelatihan, Keterandalan Laporan Keuangan. 


\section{Pendahuluan}

Pengelolaan keuangan pemerintah dilakukan berdasarkan tata kelola pemerintahan yang baik, yaitu pengelolaan keuangan dilakukan secara transparan dan akuntabel, dapat memberikan informasi kepada pemakai laporan keuangan tentang informasi hasil yang dicapai dalam penyelenggaraan pemerintahan. Pemerintah daerah sebagai entitas pelaporan yang terdiri dari satu atau lebih entitas akuntansi yang menurut Undang-Undang Nomor 17 Tahun 2003 Gubernur/Bupati/Walikota wajib menyampaikan laporan pertanggungjawaban berupa laporan keuangan daerah.

Laporan keuangan pemerintah daerah sangat penting untuk digunakan sebagai dasar pengambilan keputusan ekonomi, sosial, dan politik, maka laporan keuangan yang disajikan harus dapat diandalkan. Terwujudnya laporan keuangan yang andal, informasi keuangan yang dihasilkan harus disajikan secara wajar bebas dari salah saji yang material sehingga tidak menyesatkan pembaca dan pengguna laporan keuangan.

Sesuai dengan Peraturan Pemerintah Nomor 71 Tahun 2010 menyatakan bahwa informasi dalam laporan keuangan bebas dari pengertian yang menyesatkan dan kesalahan material, menyajikan setiap fakta secara jujur, dapat diverifikasi, dan tidak berpihak pada kebutuhan pihak tertentu. Informasi mungkin relevan, tetapi jika hakikat atau penyajiannya tidak dapat diandalkan maka penggunaan informasi tersebut secara potensial dapat menyesatkan.

Secara umum, banyak faktor yang mempengaruhi terhadap keterandalan laporan keuangan daerah. Untuk meningkatkan keterandalan laporan keuangan daerah terdapat beberapa faktor yang menentukan diantaranya adalah komitmen organisasi, pengendalian intern akuntansi, peran internal audit, pendidikan, dan kualitas pelatihan.

Mowday et al. (1982) menyatakan bahwa komitmen yang kuat dalam organisasi akan dapat menciptakan keyakinan dan dukungan serta loyalitas karyawan terhadap nilai dan sasaran yang ingin dicapai organisasi. Hal ini menunjukkan bahwa komitmen organisasi sangat penting karena memiliki hubungan yang erat dengan kinerja pegawai, di mana setiap pegawai dituntut memiliki kinerja yang baik dalam pekerjaannya.

Kekuatan komitmen bagi sebuah pemerintah daerah tidak cukup untuk menjamin terlaksananya tata kelola dan pertanggunjawaban keuangan yang baik, namun (Mahmudi, 2015:20-26) untuk menjamin terlaksananya tata kelola dan pertanggunjawaban keuangan yang baik, harus didukung oleh adanya pengendalian intern akuntansi yang memungkinkan organisasi untuk meyakini agar setiap transaksi telah melalui: (1) sistem dan prosedur akuntansi; (2) proses otorisasi; (3) didukung dengan formulir, dokumen, dan catatan akuntansi; (4) beberapa fungsi terkait yang telah dilakukan pemisahan tugas; (5) kode akun atas setiap transaksi.

Peran internal audit/inspektorat sebagai aparat pengawas internal pada pemerintah daerah melaksanakan fungsi kegiatan audit, reviu, evaluasi, dan pemantauan terhadap penyelenggaran tugas dan fungsi organisasi dalam rangka memberikan keyakinan yang memadai bahwa kegiatan telah dilaksanakan sesuai dengan tolak ukur yang telah ditetapkan serta memberikan saran-saran perbaikannya (AAIPI, 2013).

Salah satu faktor yang sangat berperan dalam mewujudkan laporan keuangan yang andal adalah pendidikan. Sutirna dan Asep (2015:25) mengatakan pendidikan adalah merupakan usaha sadar, membentuk manusia memiliki intelektual yang paripurna, memberikan bekal untuk manusia yang akan digunakan dalam beraktifitas sehari-hari. Untuk meningkatkan keterandalan laporan keuangan tidak terlepas juga kualitas pelatihan yang diperolah oleh karyawan dalam mengikuti pelatihan. Andrew (2011) mengatakan pelatihan sebagai proses pendidikan jangka pendek yang menggunakan cara dan prosedur yang sistematis dan terorganisasi. Para peserta pelatihan akan mempelajari pengetahuan dan ketrampilan yang sifatnya praktis untuk tujuan tertentu.

Faktor-faktor penentu yang diuraikan di atas dalam prakteknya tidak berjalan sesuai dengan yang diharapan dengan kondisi yang terjadi, sehingga mengakibatkan laporan keuangan yang disajikan tidak dapat diandalkan. Seperti kondisi yang terjadi di Kabupaten Halmahera 
Utara. Hal ini dibuktikan dengan hasil temuan BPK nomor LHP: 18.a/LHP/XIX.TER/6/2016/tanggal 8 Juni 2016. Pertama, terdapat penggunaan kas untuk kepentingan pribadi bendahara yang belum dipertanggungjawabkan (Ketekoran kas di bendahara pengeluaran Dinas Pertanian dan bendahara pengeluaran Badan Pemberdayaan Masyarakat dan Pemerintah Desa). Kedua, belanja hibah direalisasikan untuk kepentingan yang tidak sesuai dengan tujuan penganggarannya.

Berdasarkan pemikiran tersebut, hal yang menjadi fokus dalam penelitian ini, yaitu: Komitmen Organisasi, Pengendalian Intern Akuntansi, Peran Internal Audit, Pendidikan, dan Kualitas Pelatihan Terhadap Keterandalan Laporan Keuangan Pada SKPD Pemerintah Kabupaten Halmahera Utara.

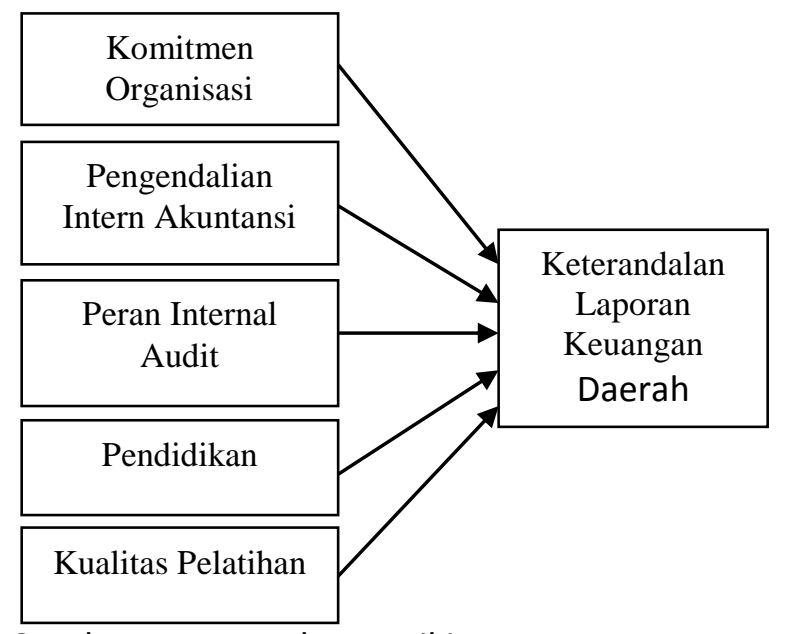

Gambar 1. Kerangka Pemikiran

Wibowo (2015:188) mengatakan komitmen organisasi berkaitan dengan tingkat keterlibatan orang dengan organisasi dimana mereka bekerja dan tertarik untuk tetap tinggal dalam organisasi tersebut serta kesediaan orang untuk meningkatkan diri dan menunjukkan loyalitas pada organisasi karena mersakan dirinya terlibat dalam kegiatan organisasi. Carsten dan Spector dalam Adifitya (2014:837) mengatakan bahwa semakin tinggi komitmen organisasi maka akan berdampak pada karyawan akan tetap tinggal dalam organisasi dan akan selalu meningkatkan kinerjanya. Kinerja karyawan yang tinggi akan menghasilakan laporan keuangan yang andal.

Pengendalian intern akuntansi merupakan sistem pengendalian intern yang terintegral dari tindakan dan kegiatan yang dilakukan oleh manajemen (eksekutif) dan jajarannya untuk memberikan jaminan atau keyakinan yang memadai atas tercapainya tujuan organisasi yang tercermin dari penyajian laporan keuangan yang andal melalui kegiatan yang efektif dan efisien, pengamanan aset negara, ketelitian dan keandalan data akuntansi (Mahmudi, 2015: 20). Pengendalian intern dalam akuntansi memiliki peranan penting karena dapat mengontrol, mengawasi, mengarahkan organisasi agar dapat mencapai suatu tujuan.

Internal audit adalah suatu fungsi penilaian yang independen yang diterapkan dalam suatu organisasi yang berfungsi untuk menguji dan mengevaluasi kegiatan organisasi sebagai jasa yang diberikan kepada organisasi tersebut. Dengan kata lain, internal audit merupakan pemeriksaan yang dilakukan oleh karyawan perusahaan bersangkutan yang disebut akuntan intern yang tidak terlibat dalam kegiatan akuntansi dan kegiatan operasi perusahaan (Sunyoto, 2013:7).

Sutirna dan Asep (2015:36) megatakan pendidikan merupakan pembelajaran pengetahuan, keterampilan, dan kebiasaan kelompok yang diturunkan dari suatu generasi ke generasi berikutnya melalui pengajaran, pelatihan, atau penelitian. Pendidikan dapat membentuk manusia yang paripurna, memberikan bekal untuk manusia yang akan digunakan dalam beraktifitas sehari-hari, dan pesan moral yang baik bagi pengembangan hidup dan kehidupannya dimasa kini dan masa yang akan datang. 


\section{Metode Penelitian}

Penelitian ini menggunakan jenis penelitian kuantitatif yang berbentuk asosiatif menggunakan data primer yang bertujuan untuk menguji hipotesa mengenai pengaruh komitmen organisasi, pengendalian intern akuntansi, peran internal audit, pendidikan, dan kualitas pelatihan terhadap keterandalan laporan keuangan. Teknik analisis yang digunakan dalam penelitian ini adalah analisis regresi linier berganda.

Populasi dalam penelitian ini adalah 298 pegawai pengelola keuangan pada 47 Satuan Perangkat Daerah (SKPD). Sampel dalam penelitian ini adalah pegawai pada bagian proses penatausahaan keuangan dan pegawai yang membuat laporan keuangan sebanyak 75 yang tersebar di 30 SKPD. Pengambilan sampel dari populasi pada penelitian ini dilakukan dengan teknik proposive sampling.

\section{Hasil dan Pembahasan}

Data dalam penelitian ini dikumpulkan dengan cara menyebarkan kuesioner langsung kepada objek penelitian. Peneliti mengantarkan langsung kuesioner kepada responden untuk mengantisipasi terjadinya respond rate yang rendah pada saat pengembalian kuesioner.

Uji validitas bertujuan untuk mengukur valid atau tidaknya suatu item pertanyaan. Untuk menguji kebenaran hipotesis pada penelitian ini digunakan uji validitas data yang diperoleh dengan menguji tiap kuesioner yang ada dengan nilai korelasi minimal 0,30. Untuk mendapatkan kualitas data dari hasil penelitian, maka dilakukan uji validitas dengan menggunakan Pearson Correlation dimana hasil uji validitas menunjukkan bahwa semua item pertanyaan untuk variabel komitmen organisasi, pengendalian intern akuntansi, peran internal audit, pendidikan, kualitas pelatihan, dan keterandalan laporan keuangan memiliki nilai Pearson Correlation diatas 0,30. Artinya semua item pertanyaan dinyatakan valid.

Uji reliabilitas bertujuan untuk mengukur konsisten atau tidaknya jawaban dari seseorang terhadap setiap item pertanyaan yang terdapat dalam sebuah kuesioner. Untuk mengetahui apakah jawaban yang diberikan responden dapat dipercaya atau dapat diandalkan maka digunakan analisis reability melalui metode cronbach alpha, dimana suatu instrumen dikatakan reliabel bila memiliki koefisen keandalan atau alpha sebesar 0,6 atau lebih. Hasil uji reliabilitas menunjukkan bahwa nilai cronbach's alpha untuk komitmen organisasi sebesar 0,872, pengendalian intern akuntansi sebesar 0,922, peran internal audit sebesar 0,961, pendidikan sebesar 0,967, kualitas pelatihan sebesar 0,951, dan keterandalan laporan keuangan sebesar 0,929 . Dengan demikian dapat disimpulkan bahwa bahwa semua item pertanyaan untuk 6 (enam) variabel dinyatakan reliable karena memiliki nilai Cronbach's Alpha $>0,60$.

Uji normalitas bertujuan untuk menguji apakah dalam model regresi, variabel terikat dengan variabel bebas keduanya mempunyai distribusi normal atau tidak. Hasil uji normalitas Kolmogorov Sumirnov (K-S) menunjukkan nilai Asymp Sig sebesar 0,097. Karena nilai Asymp Sig diatas 0,05, dinyatakan nilai residual menyebar secara normal, maka model regresi yang digunakan dalam penelitian ini telah memenuhi asumsi normalistas.

Uji multikolinieritas digunakan untuk menguji apakah dalam model regresi ditemukan adanya korelasi antara variabel bebas. Model regresi yang baik harusnya tidak terjadi korelasi diantara variabel bebas. Hasil coefficients pada output coefficients model, dikatakan tidak terjadi gejala multikolinearitas jika mempunyai nilai tolerance di atas 0,1 atau VIF $<10$. Berdasarkan hasil uji multikolinieritas diketahui bahwa nilai tolerance dari masing-masing variabel independen di atas 0,1 dan nilai VIF dari masing-masing variabel independen lebih kecil dari pada 10, yaitu nilai VIF untuk variabel komitmen organisasi (X1) adalah sebesar $1.053<10$ dan nilai tolerance 0,950 >0,10; nilai VIF untuk variabel pengendalian intern akuntansi (X2) adalah sebesar $1.034<10$ dan nilai tolerance 0,968 >0,10; nilai VIF untuk variabel peran inter internal audit (X3) adalah sebesar $1.059<10$ dan nilai tolerance 0,944 $>0,10$; nilai VIF untuk variabel pendidikan (X4) adalah sebesar $1.054<10$ dan nilai tolerance 0,948 > 0,10; nilai VIF untuk 
variabel kualitas pelatihan (X5) adalah sebesar $1.018<10$ dan nilai tolerance 0,983 > 0,10. Dengan demikian dapat disimpulkan bahwa tidak terjadi gejala multikolinearitas antara variabel komitmen organisasi, pengendalian intern akuntansi, peran internal audit, pendidikan, dan kualitas pelatihan dalam model penelitian ini.

Uji heterokedastisitas digunakan untuk menguji apakah dalam model regresi terjadi ketidaksamaan variance dari residual satu pengamatan ke pengamatan lain. Model regresi yang baik harusnya tidak terjadi ketidaksamaan variance dari residual satu pengamatan ke pengamatan lain. Jika probabilitas signifikansi masing-masing variabel independen $>0,05$, maka dapat disimpulkan tidak terjadi heteroskedastisitas dalam model regresi. Berdasarkan hasil uji heteroskedastisitas diketahui bahwa nilai signifikansi dari komitmen organisasi sebesar 0,838, pengendalian intern akuntansi sebesar 0,165 , peran internal audit sebesar 0,805 , pendidikan sebesar 0,276, kualitas pelatihan sebesar 0,745 lebih besar dari 0,05 yang berarti bahwa tidak terjadi heterokedastisitas sehingga uji regresi dapat dilajutkan.

Model regresi berganda dalam penelitian ini adalah untuk menguji komitmen organisasi, pengendalian intern akuntansi, peran internal audit, pendidikan, dan kualitas pelatihan terhadap keterandalan laporan keuangan. Hasil analisis regresi berganda adalah sebagai berikut.

Tabel 1.

Koefisien Regresi

\begin{tabular}{|c|l|r|r|}
\hline \multicolumn{2}{|c|}{ Model } & \multicolumn{2}{c|}{$\begin{array}{c}\text { Unstandardized } \\
\text { Coefficients }\end{array}$} \\
\cline { 3 - 4 } \multicolumn{2}{|c|}{1} & B & Std. Error \\
\hline \multirow{4}{*}{1} & (Constant) & 1,452 & 4,633 \\
\cline { 2 - 4 } & Komitmen Organisasi & 0,373 & 0,087 \\
\cline { 2 - 4 } & Pengendalian Intern Akuntansi & 0,171 & 0,053 \\
\cline { 2 - 4 } & Peran Internal Audit & 0,201 & 0,055 \\
\cline { 2 - 4 } & Pendidikan & 0,144 & 0,049 \\
\cline { 2 - 4 } & Kualitas Pelatihan & 0,131 & 0,037 \\
\hline
\end{tabular}

Hasil tersebut bila dimasukkan ke dalam persamaan penelitian menjadi :

$Y=\alpha+\beta 1 X 1+\beta 2 X 2+\beta 3 X 3+\beta 4 X 4+\beta 5 X 5+e$

$Y=1.452+0,373 X_{1}+0,171 X_{2}+0,201 X_{3}+$

$0,144 x_{4}+0,131 X_{5}+e$

Tabel 2.

Hasil Uji t

\begin{tabular}{|c|c|c|c|c|c|c|}
\hline & \multirow[t]{2}{*}{ Model } & \multicolumn{2}{|c|}{$\begin{array}{l}\text { Unstandardize } \\
\text { d Coefficients }\end{array}$} & \multirow{2}{*}{$\begin{array}{c}\begin{array}{c}\text { Standar } \\
\text { dized } \\
\text { Coeffic } \\
\text { ients }\end{array} \\
\text { Beta }\end{array}$} & \multirow[t]{2}{*}{$\mathrm{T}$} & \multirow[t]{2}{*}{ Sig. } \\
\hline & & B & $\begin{array}{l}\text { Std. } \\
\text { Error }\end{array}$ & & & \\
\hline \multirow[t]{6}{*}{1} & (Constant) & 1,452 & 4,633 & & 0,313 & 0,755 \\
\hline & Komitmen Organisasi & 0,373 & 0,087 & 0,382 & 4,298 & 0,000 \\
\hline & Pengendalian Intern Akuntansi & 0,171 & 0,053 & 0,284 & 3,227 & 0,002 \\
\hline & Peran Internal Audit & 0,201 & 0,055 & 0,326 & 3,654 & 0,001 \\
\hline & Pendidikan & 0,144 & 0,049 & 0,262 & 2,949 & 0,004 \\
\hline & Kualitas Pelatihan & 0,131 & 0,037 & 0,310 & 3,541 & 0,001 \\
\hline
\end{tabular}

Diketahui hasil uji t diperoleh nilai variabel X1 thitung 4,298 $>t_{\text {tabel }}$ 1,669 dengan demikian $\mathrm{H}_{1}$ diterima atau dengan kata lain variabel komitmen organisasi $\left(X_{1}\right)$ berpengaruh posistif dan signifikan secara statistik terhadap keterandalan laporan keuangan $(\mathrm{Y})$. Diketahui hasil uji $\mathrm{t}$ diperoleh nilai variabel $X_{2} t_{\text {hitung }} 3,227>t_{\text {tabel }} 1,669$ dengan demikian $H_{2}$ diterima atau dengan kata lain variabel pengendalian intern akuntansi $\left(\mathrm{X}_{2}\right)$ berpengaruh posistif dan signifikan secara statistik terhadap keterandalan laporan keuangan (Y). Diketahui hasil uji t diperoleh nilai variabel $\mathrm{X}_{3} t_{\text {hitung }} 3,654>t_{\text {tabel }}$ 1,669 dengan demikian $\mathrm{H}_{3}$ diterima atau dengan kata lain variabel peran internal audit $\left(\mathrm{X}_{3}\right)$ berpengaruh posistif dan signifikan secara statistik terhadap keterandalan laporan keuangan $(Y)$. Diketahui hasil uji t diperoleh nilai variabel $X_{4} t_{\text {hitung }} 2,949>t_{\text {tabel }} 1,669$ dengan demikian $\mathrm{H}_{4}$ diterima atau dengan kata lain variabel pendidikan $\left(\mathrm{X}_{4}\right)$ berpengaruh posistif dan signifikan secara statistik terhadap keterandalan laporan keuangan $(\mathrm{Y})$. Diketahui hasil uji $\mathrm{t}$ 
untuk variabel kualitas pelatihan $\left(X_{5}\right)$ Nilai thitung adalah 3,541 dengan tingkat signifikansi 0,001 . Pada derajat kebebasan $(n-k) 68-6=62$, dapat diketahui nilai variabel $X_{5} t_{\text {hitung }} 3,541>t_{\text {tabel }}$ 1,669 dengan demikian $\mathrm{H}_{5}$ diterima atau dengan kata lain variabel kualitas pelatihan $\left(\mathrm{X}_{5}\right)$ berpengaruh posistif dan signifikan secara statistik terhadap keterandalan laporan keuangan $(\mathrm{Y})$

Nilai koefisien determinasi atau $\mathrm{R}^{2}$ adalah sebesar 0,497 atau 49,70\%. Angka tersebut berarti sebesar $49,70 \%$ Keterandalan Laporan Keuangan pada SKPD Pemerintah Kabupaten Halmahera Utara dapat dijelaskan oleh variabel Komitmen Organisasi $\left(X_{1}\right)$, Pengendalian Intern Akuntansi $\left(\mathrm{X}_{2}\right)$, Peran Internal Audit $\left(\mathrm{X}_{3}\right)$, Pendidikan $\left(\mathrm{X}_{4}\right)$, dan Kualitas Pelatihan $\left(\mathrm{X}_{5}\right)$. Sedangkan sisanya $(100 \%-49,70 \%=50,30 \%)$ disebabkan oleh faktor-faktor lain diluar pengujian ini. Koefisien korelasi (R) sebasar 0,731 menunjukkan bahwa hubungan (korelasi) antara variabel independen dengan variabel dependen merupakan hubungan yang kuat. Artinya Komitmen Organisasi $\left(X_{1}\right)$, Pengendalian Intern Akuntansi $\left(X_{2}\right)$, Peran Internal Audit $\left(X_{3}\right)$, Pendidikan $\left(X_{4}\right)$, dan Kualitas Pelatihan $\left(X_{5}\right)$ terhadap keterandalan laporan keuangan mempunyai hubungan yang kuat.

\section{Pengaruh Komitmen Organisasi Terhadap Keterandalan Laporan Keuangan}

Hasil pengujian menunjukan bahwa variabel komitmen oragniasai berpengaruh positif dan signifikan secara statistik terhadap keterandalan laporan keuangan Pemerintah Daerah Kabupaten Halmahera Utara. Dengan demikian hipotesis 1 terdukung karena secara empirik terbukti. Hal ini menunjukkan bahwa keterandalan laporan keuangan didukung oleh komitmen organisasi.

Temuan ini sesuai dengan penelitian sebelumnya yang dilakukan oleh Fransiska (2015) menyatakan bahwa komitmen organisasi berpengaruh positif signifikan terhadap keandalan pelaporan keuangan. Temuan ini juga sesuai dengan penelitian sebelumnya dilakukan oleh Suwanda (2015) menyatakan komitmen organisasi berpengaruh terhadap kaualitas laporan keuangan. Temuan ini tidak mendukung hasil penelitian sebelumnya mengenai pengaruh komitmen organisasi terhadap keterandalan dan ketepatwaktuan pelaporan keuangan seperti penelitian Rachmawati (2014).

Temuan ini sejalan dengan teori yang dikemukakan oleh Carsten dan Spector dalam Adiftiya (2014:837) mengatakan bahwa semakin tinggi komitmen organisasi maka akan berdampak pada karyawan akan tetap tinggal dalam organisasi dan akan selalu meningkatkan kinerjanya. Kinerja karyawan yang tinggi akan menghasilakan laporan keuangan yang andal. Tingginya komitmen organiasi akan meningkatkan keterandalan laporan keuangan Pemerintah Daerah Kabupaten Halmahera Utara.

\section{Pengaruh Pengendalian Intern Akuntansi Terhadap Keterandalan Laporan Keuangan}

Hasil pengujian menunjukan bahwa variabel pengendalian intern akuntansi berpengaruh positif dan signifikan secara statistik terhadap keterandalan laporan keuangan Pemerintah Daerah Kabupaten Halmahera Utara. Dengan demikian hipotesis 2 terdukung karena secara empirik terbukti. Hal ini menunjukkan bahwa keterandalan laporan keuangan didukung oleh pengendalian intern akuntansi.

Temuan ini sesuai dengan penelitian sebelumnya yang dilakukan oleh Prasetyo (2015), Desmiyawati (2014), dan Megayanti, et al. (2015) menyatakan bahwa pengendalian intern akuntansi pengaruh positif dan siknifikan terhadap keterandalan pelaporan keuangan pemerintah.

Temuan ini sejalan dengan teori yang dikemukakan oleh Mahmudi (2015:20) yang menyatakan bahwa untuk menjamin terlaksananya tata kelola dan pertanggunjawaban keuangan yang baik, harus didukung oleh adanya pengendalian intern akuntansi yang memungkinkan melalui kegiatan pengendalian sistem dan prosedur akuntansi, proses otorisasi, formulir/dokumen dan catatan, pemisahan fungsi secara tegas, dan menggunakan kode akun yang tersedia. Informasi keuangan yang dihasilakan dapat memberikan jaminan atau keyakinan 
yang memadai atas tercapainya tujuan organisasi yang tercermin dari keandalan laporan keuangan yang disajikan.

\section{Pengaruh Peran Internal Audit Terhadap Keterandalan Laporan Keuangan}

Hasil pengujian menunjukan bahwa variabel peran internal audit berpengaruh positif dan signifikan secara statistik terhadap keterandalan laporan keuangan Pemerintah Daerah Kabupaten Halmahera Utara. Dengan demikian hipotesis 3 terdukung karena secara empirik terbukti. Hal ini menunjukkan bahwa keterandalan laporan keuangan didukung oleh peran internal audit.

Temuan ini sesuai dengan penelitian sebelumnya yang dilakukan oleh Purwanti dan Wasman (2014), Nova (2015) menyatakan bahwa peran internal audit/inspektorat berpengaruh positif dan signifikan terhadap kualitas laporan keuangan pemerintah daerah. Artinya, peran iternal audit/inspektorat berpengaruh memberikan perubahan yang berarti terhadap kualitas laporan keuangan.

Temuan ini sejalan dengan teori yang dikemukakan oleh Mahmudi, (2011:255) mengatakan peran aparat pengawasan internal pemerintah yang efektif dapat memberikan keyakinan yang memadai atas ketaatan, kehematan, efisiensi, efektivitas pencapaian tujuan penyelenggaraan tugas dan fungsi instansi pemerintah, memberikan peringatan dini, memelihara dan meningkatkan kualitas tata kelola penyelenggaraan tugas dan fungsi instansi pemerintah. Inspektorat provinsi/kabupaten

/kota sebagai pengawas internal pemerintah daerah melakukan pengawasan terhadap seluruh proses kegiatan audit, evaluasi, reviu, dan pemantauan dalam rangka memberikan keyakinan yang memadai bahwa kegiatan telah dilaksankan sesuai dengan tolak ukur yang telah ditetapkan secara efektif dan efisien untuk kepentingan pimpinan dalam rangka mewujudkan pemerintahan yang baik.

\section{Pengaruh Pendidikan Terhadap Keterandalan Laporan Keuangan}

Hasil pengujian menunjukan bahwa variabel pendidikan berpengaruh positif dan signifikan secara statistik terhadap keterandalan laporan keuangan Pemerintah Daerah Kabupaten Halmahera Utara. Dengan demikian hipotesis 4 terdukung karena secara empirik terbukti. Hal ini menunjukkan bahwa keterandalan laporan keuangan didukung oleh pendidikan.

Temuan ini sesuai dengan penelitian sebelumnya yang dilakukan oleh Nastiti (2013) menyatakan bahwa pendidikan berpengaruh positif dan signifikan terhadap kualitas penyajian informasi akuntansi. Temuan ini juga konsisten dengan penelitian yang dilakukan oleh Muzahid (2014) menyatakan bahwa pendidikan berpengaruh positif dan signifikan terhadap kualitas laporan keuangan.

Temuan ini sejalan dengan teori yang dikemukakan oleh Sutirna dan Asep (2015:25) menyatakan bahwa pendidikan merupakan usaha sadar, membentuk manusia memiliki intelektual yang paripurna, memberikan bekal untuk manusia yang akan digunakan dalam beraktifitas sehari-hari, dan pesan moral yang baik bagi pengembangan hidup dan kehidupannya dimasa kini dan masa yang akan datang. Peningkatan kemampuan intelektual atau emosional yang diperlukan untuk melaksanakan pekerjaan yang lebih baik.

\section{Pengaruh Kualitas Pelatihan Terhadap Keterandalan Laporan Keuangan}

Hasil pengujian menunjukan bahwa variabel kualitas pelatihan berpengaruh positif dan signifikan secara statistik terhadap keterandalan laporan keuangan Pemerintah Daerah Kabupaten Halmahera Utara. Dengan demikian hipotesis 5 terdukung karena secara empirik terbukti. Hal ini menunjukkan bahwa keterandalan laporan keuangan didukung oleh kualitas pelatihan.

Temuan ini sesuai dengan penelitian sebelumnya yang dilakukan oleh Nastiti (2013) yang menyatakan bahwa pelatihan berpengaruh positif dan signifikan terhadap kualitas penyajian 
informasi akuntansi. Temuan ini juga konsisten dengan penelitian yang dilakukan oleh Muzahid (2014) yang menyatakan bahwa kualitas pelatihan berpengaruh positif dan signifikan terhadap kualitas laporan keuangan.

Temuan ini sejalan dengan teori yang dikemukakan oleh Kaswan (2011:2) menyatakan pelatihan merupakan proses peningkatan pengetahuan dan keterampilan karyawan. Artinya pelatihan dapat mengubah sikap sehingga karyawan dapat melakukan pekerjaan lebih efektif. Pelatihan dapat dilakukan pada semua tingkat pada organisasi untuk meningkatkan pengetahuan dan keterampilan teknis. Pada tingkat staf pelatihan berisikan pengajaran bagaimana mengerjakan sesuatu pekerjaan, misalnya bagaimana cara penatausahaan dan munyusun laporan keuangan.

\section{Kesimpulan dan Saran}

Berdasarkan hasil penelitian dan pembahasan maka dapat disimpulkan beberapa kesimpulan sebagai berikut.

1. Komitmen organisasi (X1) berpengaruh positif dan siginifikan terhadap keterandalan laporan keuangan pemerintah daerah (Y). Hal ini menunjukkan bahwa semakin tinggi komitmen organisasi yang dimiliki staf keuangan/akuntansi maka semakin tinggi pula keterandalan laporan keuangan yang dihasilkan.

2. Pengendalian intern akuntansi (X2) berpengaruh positif dan signifikan terhadap keterandalan laporan keuangan pemerintah daerah (Y). Hal ini menunjukkan bahwa semakin tinggi pengendalian intern akuntansi maka semakin tinggi pula keterandalan laporan keuangan yang dihasilkan.

3. Peran internal audit (X3) berpengaruh positif dan signifikan terhadap keterandalan laporan keuangan pemerintah daerah $(\mathrm{Y})$. Hal ini menunjukkan bahwa semakin tinggi peran internal audit maka semakin tinggi pula keterandalan laporan keuangan yang dihasilkan.

4. Pendidikan (X4) berpengaruh positif dan siginifikan terhadap keterandalan laporan keuangan pemerintah daerah $(\mathrm{Y})$. Hal ini menunjukkan bahwa semakin tinggi latar belakang pendidikan akuntansi yang dimiliki oleh staf keuangan/akuntansi maka semakin tinggi pula keterandalan laporan keuangan yang dihasilkan.

5. Kualitas pelatihan (X5) berpengaruh positif dan siginifikan terhadap keterandalan laporan keuangan pemerintah daerah (Y). Hal ini menunjukkan bahwa semakin tinggi kualitas pelatihan yang dimiliki staf keuangan/akuntansi maka semakin tinggi pula keterandalan laporan keuangan yang dihasilkan.

Berdasarkan hasil penelitian dan pembahasan, maka dapat dikemukakan beberapa saran sebagaimana berikut ini.

1. Saran bagi pemerintah daerah Kabupateh Halmahera Utara:

a) Komitmen organisasi sangat penting dalam meningkatkan keterandalan laporan keuangan, oleh karena itu pegawai keuangan/akuntansi untuk terus meningkatkan komitmen dalam pelaksanaan tugas pengelolaan keuangan.

b) Pengendalian intern akuntansi sangat penting dalam meningkatkan keterandalan laporan keuangan, oleh karena itu (1) perlu meningkatkan penerapan sistem dan prosedur akuntansi, (1) perlu melakukan otorisasi sesuai dengan kewenangan yang diberikan oleh yang mengacu pada ketentuan dan peruundang-undangan yang berlaku, (3) perlu menggunakan formulir, dokumen dan catatan akuntansi yang didukung dangan bukti transaksi yang valid dan sah, (4) perlu ada pemisahan tugas yang antara bendahara pengeluaran dan Pejabat Penatausahaan Keuangan (PPK)/staf akuntansi.

c) Peran internal audit/inspektorat sangat penting dalam meningkatkan keterandalan laporan keuangan, oleh karena itu hendaknya peran internal audit dapat terus ditingkatkan. 
d) Tingkat pendidikan sangat penting dalam meningkatkan keterandalan laporan keuangan, oleh karena itu hendaknya pendidikan formal dan nonformal pegawai akuntansi/keuangan dapat terus ditingkatkan.

e) Kualiats Pelatihan sangat penting dalam meningkatkan keterandalan laporan keuangan, oleh karena itu hendaknya lebih selektif memilih penyelenggara pelatihan/bimtek agar materi pelatihanyang diajarkan sesuai dengan tujuan instansi.

2. Saran bagi peneliti selanjutnya, agar memperdalam hasil temuan penelitian ini dengan menambah variabel-variabel yang berperan pada keterandalan laporan keuangan.

\section{Daftar Pustaka}

Adifitya, Jajang. 2014. Pengaruh Komitmen Organisasi Terhadap Kinerja Karyawan Pada PT. Bukit Makmur Mandiri Utama Site Kideco Jaya Agung Batu Kajang Kabupaten Paser. eJournal Ilmu Administrasi Bisnis, 2014, 2 (4): 833-845 ISSN 2355-5408, ejournal.adbisnis.fisip-unmul.ac.id.

Andrew, Sikula. 2011. Manajemen Sumber Daya Manusia. Erlangga, Bandung.

Anggraeni, D,.T. 2014. Faktor-Faktor Yang Mempengaruhi KeterandalanPelaporan Keuangan Pemerintah Daerah (Studi pada SKPD di Kabupaten Sidoarjo). Jurnal IImu dan Riset Akuntansi Vol.3 No.3. STIESA Surabaya.

Agoes, Sukrisno. 2004. Auditing (Pemeriksaan Akuntan) oleh Kantor Akuntan Publik. Edisi Ketiga. Penerbit Fakultas Ekonomi Universitas Trisakti.

AAIPI. 2013. Tentang Standar Aparat Intern Pemerintah Indonesia. JakartaBPKRI. 2016. Ikhtisar Hasil Pemeriksaan Semester I. Jakarta: Badan Pemeriksa Keuangan RI.

Desmiyawati. 2014. Faktor-faktor Yang Mempengaruhi Keandalan dan Ketepatan Waktu Pelaporan Keuangan (Study Empiris Pada SKPD Pemda Riau). Jurnal Akuntansi, Vol. 2, No. 2. 163-178. ISSN 2337-4314. Fakultas Ekonomi Universitas Riau, Pekanbaru.

Dewey, John. 1964. Democracy and Education. New York: The Macmillan Company

Edison, E., Yohny A., Imas K. 2016. Menajemen Sumber Daya Manusia: Strategi dan Perubahan Dalam Rangka Meningkatkan Kinerja Pegawai dan Organisasi. Penerbit Afabeta-Bandung.

Fransiska. 2015. Pengaruh Sumber Daya Manusia, Pengawasan Keuangan Daerah, Pemanfaatan Teknologi Informasi dan Komitmen Organisasi Terhadap Keandalan Pelaporan Keuangan Pemerintah Daerah (Studi Pada Satuan Kerja Perangkat DaerahKabupaten Labuhan Batu). Jom FEKON Vol. 2 No. 2. Fakultas Ekonomi Universitas Riau, Pekanbaru.

Ghozali, Imam. 2013. Aplikasi Analisis Multivariate Dengan Program IBM SPSS21. Penerbit Badan Penerbit Universitas Diponegoro.

Hery. 2013. Setiap Auditor Harus Baca Buku Ini. PT. Grasindo, anggota IKAPI Jakarta.

Jensen, M. C. and W. H. Meckling. 1976. Theory of Firm: Managerial Behaviour, Agency Cost \& Ownership Structure. Journal of Financial Economics. Oktober. (Vol.3): No. 4: 305-306.

Jogiyanto, Hartono. 2011. Pedoman Survei Kuesioner (Pengembangan Kuesioner, Mengatasi Bias dan Meningkatkan Respon) Edisi Ke 2. PenerbitUII Press Yogyakarta.

Inapty, A., F., B. dan Sri, P., M. 2016.

Pengaruh Penerapan Standar Akuntansi Pemerintahan, Kompetensi Aparatur Dan Peran Internal Audit Terhadap Kualitas Informasi Laporan Keuangan Dengan Sistem Pengendalian Intern Sebagai Variabel Moderating (studi empiris pada SKPD-SKPD di Pemprov. NTB). Akuntabilitas: Jurnal IImu Akuntansi. Vol 9 (1), P-ISSN:1979-858X:EISSN:2461-1190 Page 2742.

Kaswan. 2011. Pelatihan dan Pengembangan Untuk Meningkatkan Kinerja SDM. Penerbit Alfabeta.

Mahmudi. 2015. Analisis Laporan Keuangan Pemerintah Daerah. Penerbit UPP STIM YKPN Yogyakarta.

Mangkunegara, A., P. 2003. Perencanaan dan Pengembangan Sumber Daya Manusia. Penerbit Refika Aditama. 
Mahmudi. 2011. Akuntansi Sektor Publik. Penerbit UII Press Yogyakarta.

Megayanti, A. P., Made, P. A., Ni, K. S. 2015. Faktor-faktor Yang Mempengaruhi Keterandalan Nilai Informasi Pelaporan Keuangan Pemerintah Daerah (Studi Pada Satuan Kerja Perangkat Daerah Kabupaten Jembrana). e-Journal Universitas Pendidikan Ganesha (Volume 3 No. 1 Tahun 2015). Singaraja-Bali.

Muzahid, Mukhlisul. 2014. Pengaruh Tingkat Pendidikan, Kualitas Pelatihan, dan Lama Pengalaman Kerja Pegawai Terhadap Kualitas Laporan Keuangan Satuan Kerja Perangkat Daerah (SPKDP) di Kabupaten Aceh Utara. Jurnal Akuntansi. Media Riset Akuntansi \& keuangan, 179-196. Politeknik Negeri Lhokseumawe.

Mulyadi. 2002. Auditing. Buku Dua, Edisi Ke Enam, Penerbit Salemba Empat, Jakarta.

Mulyadi. 2001.Sistem Akuntansi. Edisi ketiga. Penerbit Salemba Empat Jakarta.

Mowday, R.T., L.W. Porter, and R.M. Steers, 1982, Employee-Organization Linkages: The Psychology of Commitment, Absenteeism and Turnover. San Diego, CA: Academic Press.

Nastiti, Anugraheni., D. 2013. Pengaruh Pendidikan, Pelatihan dan Pengalaman Kerja terhadap Kualitas Penyajian Informasi Akuntansi (Studi Kasus pada PT. Bank Rakyat Indonesia di Kota Magelang). Jurnal Fakultas Ekonomi dan Bisnis Universitas Dian Nuswantoro. Semarang.

Nitisemito S., Alex. 2010, Manajemen Personalia, Ghalia Indonesia, Jakarta.

Nova, W. S. 2015. Pengaruh Pemahaman Akuntansi, Komitmen Karyawan, dan Peranan Internal Audit Terhadap Kualitas Laporan Keuangan Pemerintah Daerah. (Studi Empiris Pada Satuan Kerja Perangkat Daerah Kabupaten Sijungan). Artikel Fakultas Ekonomi Universitas Negeri Padang.

Peraturan Pemerintah Nomor 71. 2010. Tentang Standar Akuntansi Pemerintahan (SAP). Jakarta.

Purwanti, M., dan Wasman. 2014. Pengaruh pemahaman akuntansi, pemanfaatan sistem informasi akuntansi, dan peran internal audit terhadap kualitas laporan keuangan (survey pada koperasi pegawai republik Indonesia Kota Bandung). ESENSI: Jurnal Bisnis dan Manajemen. Vol.4, No.3. STIE Stembi Bandung.

Prasetyo, A. R. 2015. Pengaruh Kapasitas Sumber Daya Manusia, Pemanfaatan Teknologi Informasi, Pengendalian Interen Akuntansi dan Good Corporate Governance Terhadap Keterandalan Dan Ketepatwaktuan Pelaporan Keuangan Pemerintah (Studi Empiris Pada 32 Satuan Kerja di Polda Jambi). Jurnal Akuntansi dan Keuangan Fakultas Ekonomi dan Bisnis Universitas Jambi.

Rachmawati, A. 2014. Pengaruh Kapasitas Sumber Daya Manusia, Pemanfaatan

Teknologi Informasi, Komitmen Organisasi Dan Pengendalian Intern Akuntansi Terhadap Keterandalan Dan Ketepatwaktuan Pelaporan Keuangan Pemerintah Daerah (Studi pada Dinas Pendapatan, Pengelolaan Keuangan dan Aset Daerah Kabupaten Boyolali). Jurnal Fakultas Ekonomi Universitas Muhammadiyah Surakarta.

Sunyoto, Danang. 2013. Auditing Pemeriksaan Akuntansi. Penerbit CAPS. Yogyakarta.

Sutirna, H., dan Asep, S. 2015. Landasan Pendidikan. Penerbit Refika Aditama. Bandung.

Suwanda, Dadang. 2015. Factors Affecting Quality of Local Government Financial

Statements to Get Unqualified Opinion (WTP) of Audit Board of the Republic of Indonesia (BPK). Research Journal of Finance and Accounting. ISSN 2222-1697 (Paper) ISSN 2222-2847 (Online). Vol.6, No.4.

Undang-undang Nomor 17. 2003. Tentang Keuangan Negara. Jakarta.

Wibowo. 2015. Perilaku Dalam Organisasi. Penerbit PT Rajagrafindo Persada Jakarta. 